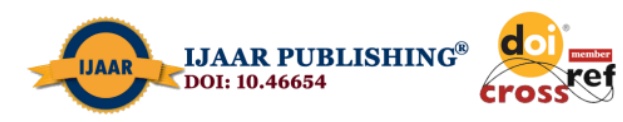

International Journal of Advanced Academic Research | ISSN: 2488-9849

Vol. 7, Issue 5 (May, 2021) | www.ijaar.org

Journal DOI: www.doi.org/10.46654/ij.24889849

Article DOI: www.doi.org/10.46654/ij.24889849.e7415

\title{
SPATIAL DISTRIBUTION OF HEAVY METAL CONTAMINATION IN GROUNDWATER OF ONITSHA URBAN, SOUTHEAST NIGERIA
}

\author{
${ }^{1}$ Okoyeh, E.I., ${ }^{1}$ Ahaneku, V.C, ${ }^{1}$ Utom, A., ${ }^{1}$ Udegbunam, I.E. and ${ }^{2}$ Egwuonwu, G. E. \\ ${ }^{1}$ Department of Geological Sciences Nnamdi Azikiwe University Awka, Nigeria \\ ${ }^{2}$ Department of Pure and Industrial Physics, Nnamdi Azikiwe University Awka, Nigeria
}

\begin{abstract}
The investigation of the degree of trace heavy metals contamination in groundwater wells in Onitsha Southeast Nigeria, was carried out based on 20 preselected sample locations. The result of the analysis revealed water of relatively high acidity with $\mathrm{pH}$ ranging from 4.93 t0 6.94. The EC values for the analysed water samples ranged from 10.80 to $60.90 u$ while TDS ranges from 20.00 to 410.00. Heavy metals in the form of Arsenic (As), Cadmium (Cd), Chromium (Cr), Iron (Fe), Nickel (Ni), Zinc ( $\mathrm{Zn})$, Vanadium (V) and Copper (Cu) were analyzed for their concentration in the water samples of the area. The study revealed that the mean value of $\mathrm{Fe}(0.832000 \pm 1.0626228 \mathrm{ppm})$ and $\mathrm{Cd}(0.043750 \pm 0.0181713 \mathrm{ppm})$ exceeded the permissible limit for NSDWQ water quality standard as indicated by the high concentrations of $\mathrm{Fe}$ and $\mathrm{Cd}$ values observed in water samples of the study area. The concentrations of the heavy metals except $\mathrm{Fe}$ and $\mathrm{Cd}$ range from $\mathrm{Ni}(0.000-0.750),(\mathrm{Cu} 0.00$ - 0.105), (Zn 0.00 - 1.798), (Cr 0.002 - 0.046), (As 0.000 - 0.056) and (Va 0.000 - 0.008). The spatial distribution of the heavy metals in the area shows that the eastern part of the study area has relative high concentration of the heavy metals which is attributed to anthropogenic impacts.
\end{abstract}

Keywords: Heavy metals, Spatial maps, Groundwater quality, Pollution/Contamination, Public health, anthropogenic activities 


\section{Introduction}

Water is important for human existence. Water in adequate quality and quantity is essential for sustainable development and maintenance of public health. Availability as well as accessibility of water is one of the basic factors that determine the living standard of an economy. The quality of public health depends greatly on the quality of groundwater (Ranjana, 2010). Groundwater quality is usually preferred when compared to surface water because it is less prone to contamination as a result of its natural filtration. Although groundwater is the major reliable source of water supply for drinking and irrigation purposes in the study area, its quality is greatly affected by both natural and man-made factors. The properties of the media through which the fluid flow constitute the natural factor that after water quality while anthropogenic activities associated with numerous commercial and industries activities resulting in the generation and indiscriminate waste disposal in the area. Water quality is significantly impacted in recent times by pollution/contamination promoting activities prevalent in developing countries. Unprecedented waste generation and poor waste management occasioned by the absence of waste treatment facilities have taken a toll in the water quality of the commercial city of Onitsha southeast, Nigeria. Pollution from diverse sources principally affects quality of water (Sajil-Kumar et al., 2013). The usability of water for any purpose such as domestic, agriculture and industrial activities depend to a great extent on the concentration of contaminants in it.

The level of contaminants in the water resources shows the suitability of water for human consumption, irrigation and/or industrial usage. The presence of contaminants above World Health Organization (WHO) standards can be dangerous depending on its usage since water not potable for drinking may be useful for irrigation purpose. Industrial effluents, agricultural waste as well as household waste may contain heavy metals. Wastes also derived from shops and small-scale industries have become numerous and may contain heavy metals. Groundwater is readily available in the study area but the quality of the available water is of great concern due to unprecedented population increase, unplanned urbanization, poor waste disposal system and total absence of waste treatment facilities. This is exacerbated by absence of functional water scheme making the inhabitants source for water supply individually. This has implication on public health as water available is never sufficient. Women, girls and children trek long distance in search of domestic water supply wasting valuable man hour. The water brought home by women/children and that supplied by water vendors is often of poor quality. There has been continuous influx of people into the study area as a result of the intense urbanization and high commercial activities. Due to the sporadic increase in the population density in the study area, the entire environment is extensively stressed and waste output is increased. Groundwater from shallow sources constitutes the final destination for these wastes since government finds it increasingly difficult to manage variable categories of wastes in this area. Therefore, there is a need to assess the quality of groundwater in the commercial city of Onitsha to determine the extent of the contamination and its spatial variation so as to ascertain the status of the groundwater in the area.

\section{The Study area}

The study area lies within latitude $6^{0} 6^{1} 0^{11} \mathrm{~N}$ to $6^{0} 11^{1} 0^{11} \mathrm{~N}$ and longitude $6^{0} 45^{1} 0^{11} \mathrm{E}$ to $6^{0} 50^{1}$

$0^{11} \mathrm{E}$ (Fig. 1). The area is drained by Niger Riverwith Nkisi River as its major tributary. Geologically, the study area is dominantly underlain by Ameki group which falls within the 
Niger delta sedimentary basin of southeastern Nigeria (Nwajide, 2013).Two main climatic periods prevail in the area, the dry season (October-March) and the rainy season (AprilSeptember). The rainfall occurs as violent downpour accompanied by thunderstorm, high runoff and heavy flooding, soil leaching and extensive sheet outwash. The area is experiencing significant variation in onset and cessation of rainfall which is attributed to climate change. There is also obvious change in rainfall intensity and duration with implications on food security (Okoro et al., 2013). The dry season is characterized by dusty atmosphere, lowering of shallow groundwater levels and drying of surface water due to excessive temperature that encourages evapotranspiration. The average annual rainfall ranges between $1800 \mathrm{~mm}$ to $2000 \mathrm{~mm}$. The mean daily and annual temperature are $30^{\circ} \mathrm{C}$ and $27^{\circ} \mathrm{C}$ respectively, while the average relative humidity ranges between $60-70 \%$ and $80-90 \%$ in January and July respectively (Monanu, 1975).

\section{Materials and Methods}

Topographic map of scale 1: 100,000 from where the study area was delineated was collected from the Department of Geological Sciences, Nnamdi Azikiwe University Awka. Rainfall data, temperature and humidity data of the area were obtained from Nigeria Meteorological Institute. 20 water samples were collected from accessible shallow wells in the area following standard practices. The water in the shallow wells was allowed to flow for about 5minutes and the sample containers rinsed two to three times with the sample to be collected before the sample was collected. The samples were carefully labeled, stored in ice pack container and then transported to the Springboard Laboratory Services Awka for analysis following APHA methods. The $\mathrm{pH}$ was determined in-situ using hand held Hanna model $\mathrm{pH}$ meter. Digital hand held EC/TDS meter was also used to measure both EC and TDS in the field. The heavy metals were determined using Atomic Absorption Spectrophotometer (AAS). The sample locations were recorded with the aid of Global Positioning System (GPS). 

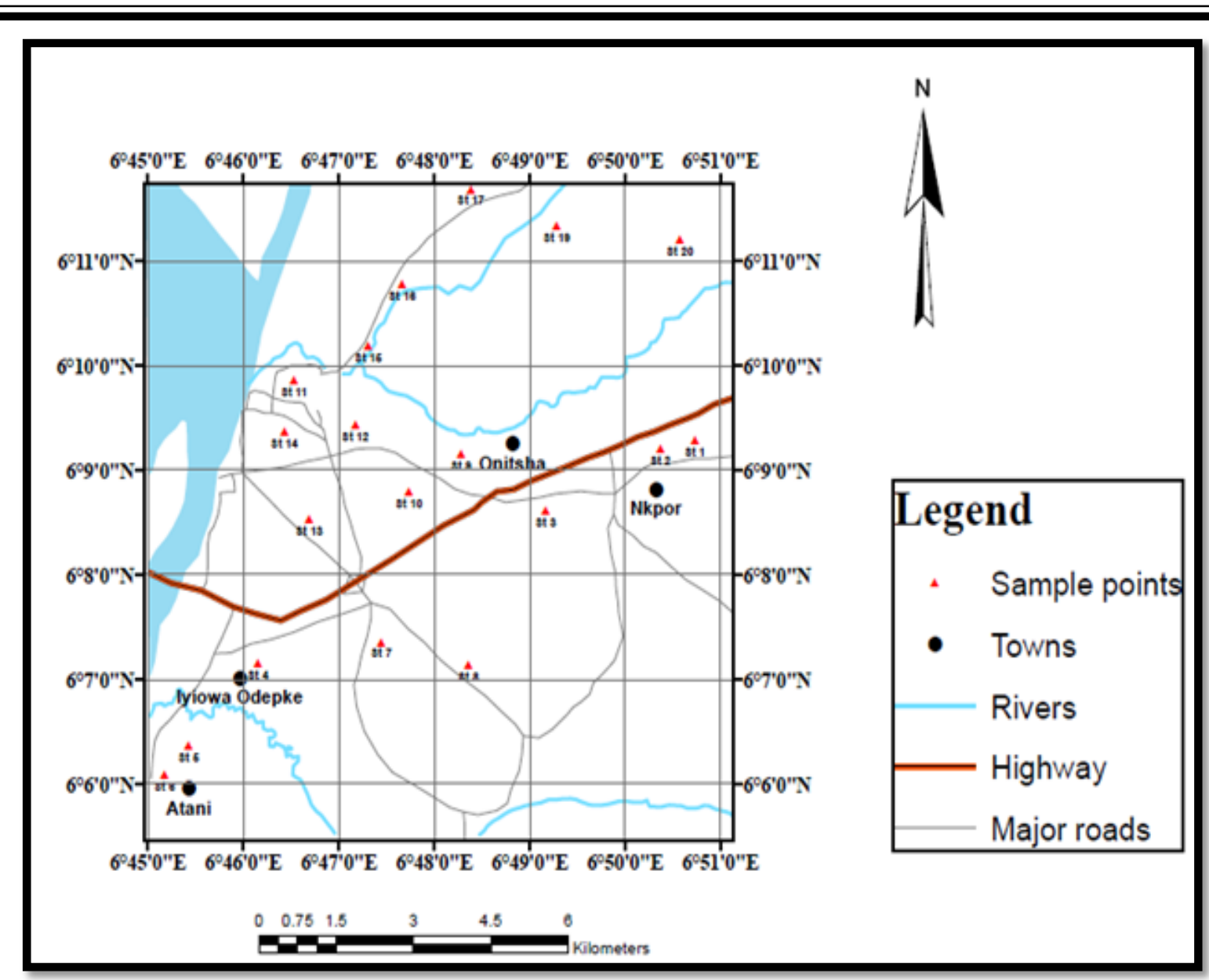

Fig 1: Map of the Study area Showing Sample Locations

\section{Results and discussion}

The result of trace heavy metal analysis compared with WHO standard and NSDWQ standard is presented in table 1 below. 
International Journal of Advanced Academic Research | ISSN: 2488-9849

Vol. 7, Issue 5 (May, 2021) | www.ijaar.org

Journal DOI: www.doi.org/10.46654/ij.24889849

Article DOI: $\underline{w w w . d o i . o r g / 10.46654 / i j .24889849 . e 7415 ~}$

Table 1: Result of trace heavy metal Analysis

\begin{tabular}{|c|c|c|c|c|c|c|c|c|c|c|}
\hline & & & Desc & iptive $S$ & tatistic & & & & & \\
\hline & $\mathrm{N}$ & Range & $\begin{array}{l}\text { Mini } \\
\text { mum }\end{array}$ & $\begin{array}{c}\text { Maxim } \\
\text { um } \\
\end{array}$ & Sum & Mean & $\begin{array}{c}\text { Std. } \\
\text { Deviation }\end{array}$ & Variance & $\begin{array}{l}\text { WHO } \\
\text { Standard } \\
(\mu \mathrm{g} / \mathrm{l})\end{array}$ & $\begin{array}{l}\text { NSDWQ } \\
\text { Standard (mg/l) }\end{array}$ \\
\hline Iron & 20 & 3.7690 & .0000 & 3.7690 & $\begin{array}{r}16.640 \\
0\end{array}$ & .832000 & 1.0626228 & 1.129 & ----- & 0.3 \\
\hline Nickel & 20 & .0750 & .0000 & .0750 & .0750 & .003750 & .0167705 & .000 & 6 & 0.02 \\
\hline Cadmium & 20 & .0760 & .0100 & .0860 & .8750 & .043750 & .0181713 & .000 & 3 & 0.003 \\
\hline Copper & 20 & .1050 & .0000 & .1050 & .3830 & .019150 & .0268490 & .001 & 50 & 0.05 \\
\hline Zinc & 20 & $\begin{array}{r}1.798 \\
0\end{array}$ & .0000 & 1.7980 & 4.9190 & .245950 & .5592674 & .313 & ---- & 3 \\
\hline Chromium & 20 & .0438 & .0022 & .0460 & .3810 & .019050 & .0111644 & .000 & 50 & 0.05 \\
\hline Arsenic & 20 & .0560 & .0000 & .0560 & .2254 & .011270 & .0152117 & .000 & 10 & 0.01 \\
\hline Vanadium & 20 & .008 & .000 & .008 & .040 & .00200 & .002596 & .000 & ----- & ----- \\
\hline $\mathrm{pH}$ & 20 & 2.01 & 4.93 & 6.94 & 113.39 & 5.6695 & .57242 & .328 & $6.5-8.5$ & $6.5-8.5$ \\
\hline Conductivity & 20 & 50.10 & 10.80 & 60.90 & 606.30 & 30.3150 & 15.16639 & 230.019 & ----- & ----- \\
\hline TDS & 20 & $\begin{array}{r}390.0 \\
0\end{array}$ & 20.00 & 410.00 & $\begin{array}{r}2440.0 \\
0\end{array}$ & $\begin{array}{r}122.000 \\
0\end{array}$ & 114.78126 & $\begin{array}{r}13174.73 \\
7\end{array}$ & ------ & 500 \\
\hline & & & & & & & & & & \\
\hline
\end{tabular}

The arsenic concentration in the analysed water samples varied from 0 to $0.056 \mathrm{ppm}$. The obtained values are below permissible limit. The relatively high concentration of Arsenic in parts of the study area could be attributed to the high commercial activities in the area (Fig.2). 


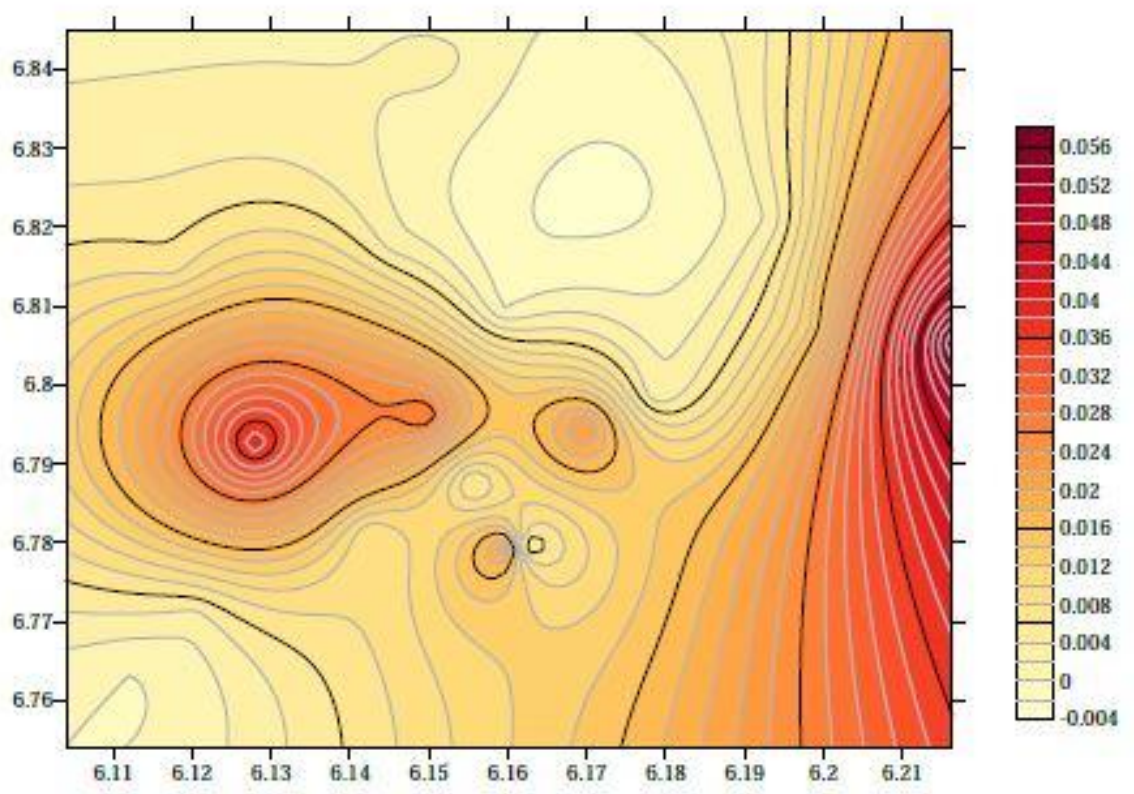

Fig. 2: Spatial Contour Map of Arsenic

The variation of cadmium in the groundwater supply sources of the study area is shown in Fig. 3. The value of the cadmium in samples ranges from 0.01 to $0.086 \mathrm{ppm}$. The northeastern part of the study area has the highest concentration of Cadmium and it exceeds the permissible limit.

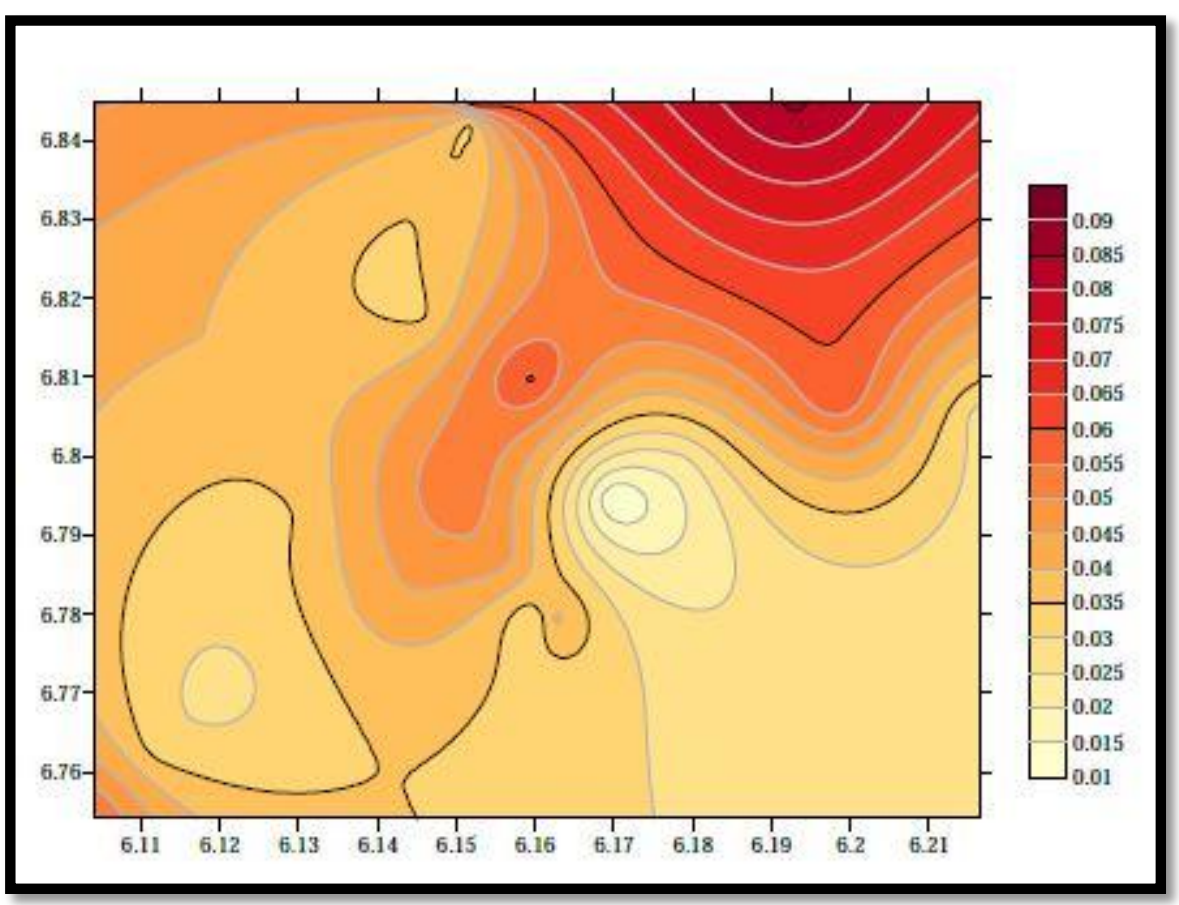

Fig. 3: Spatial Contour Map of Cadmium 
The concentration of Chromium varies from 0.002 to 0.046 and below permissible limit. The relative high concentration of Chromium in the extreme southwestern part of the study area could be attributed to agricultural activities in the area (Fig. 4)

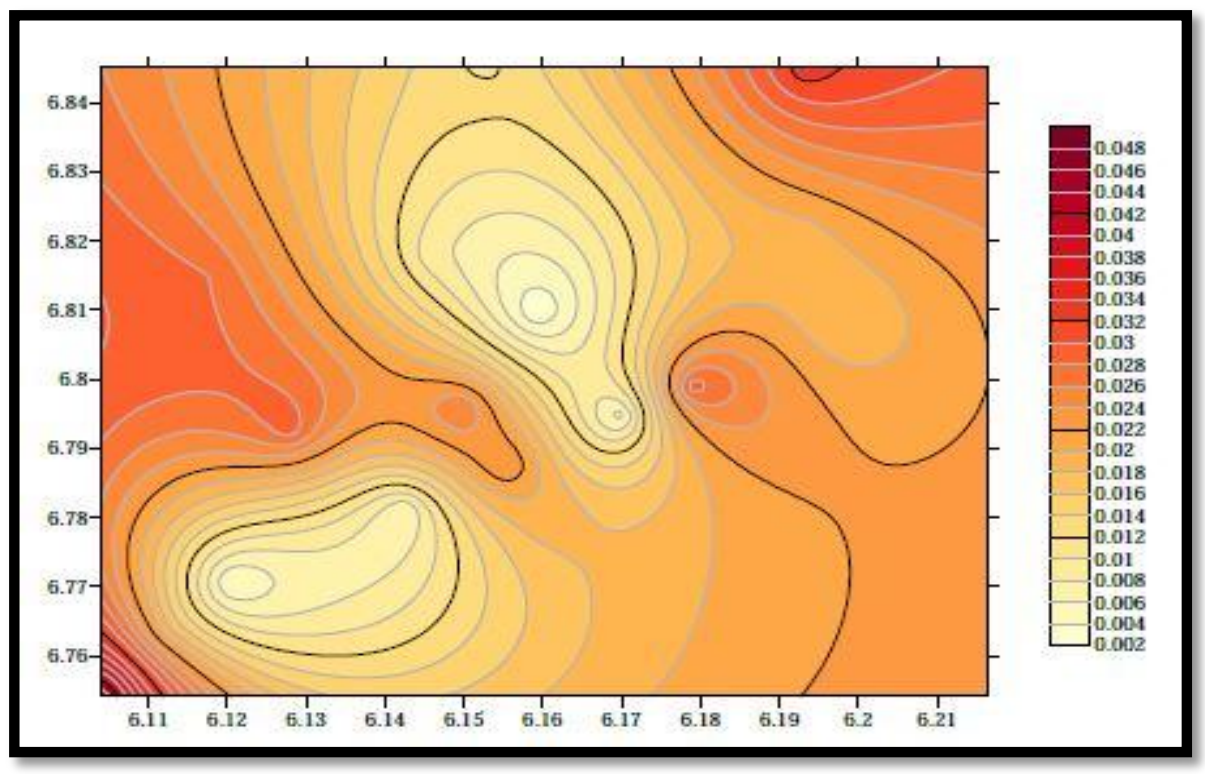

\section{Fig. 4: Spatial Contour Map of Chromium}

Figure 5 indicates that the central part of the study area has high concentration of Copper though still within the permissible limit. Copper varies from 0 to $0.105 \mathrm{ppm}$.

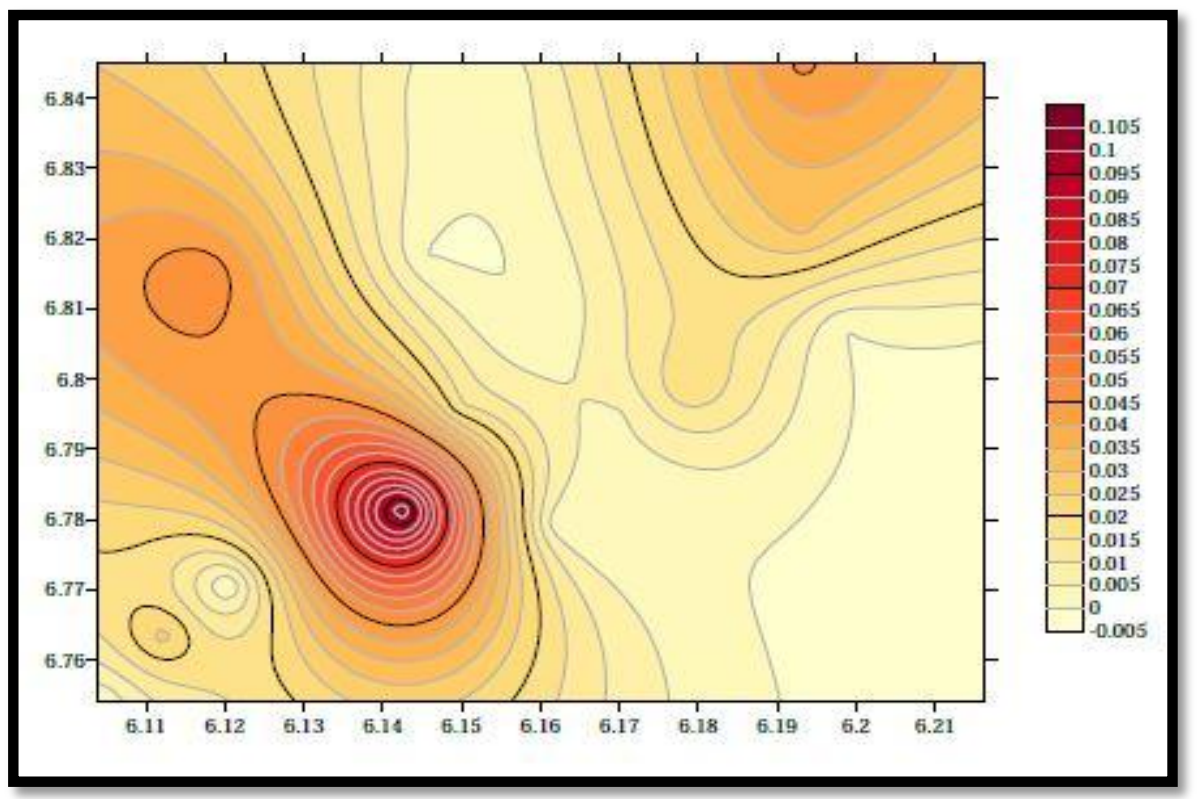

Fig. 5: Spatial Contour Map of Copper 
The spatial contour map of Electrical conductivity (EC) indicates that the groundwater in the western part of the study area is highly conductive when compared with the rest of the study area (Fig. 6). This could be as a result of unregulated disposal of untreated wastes.

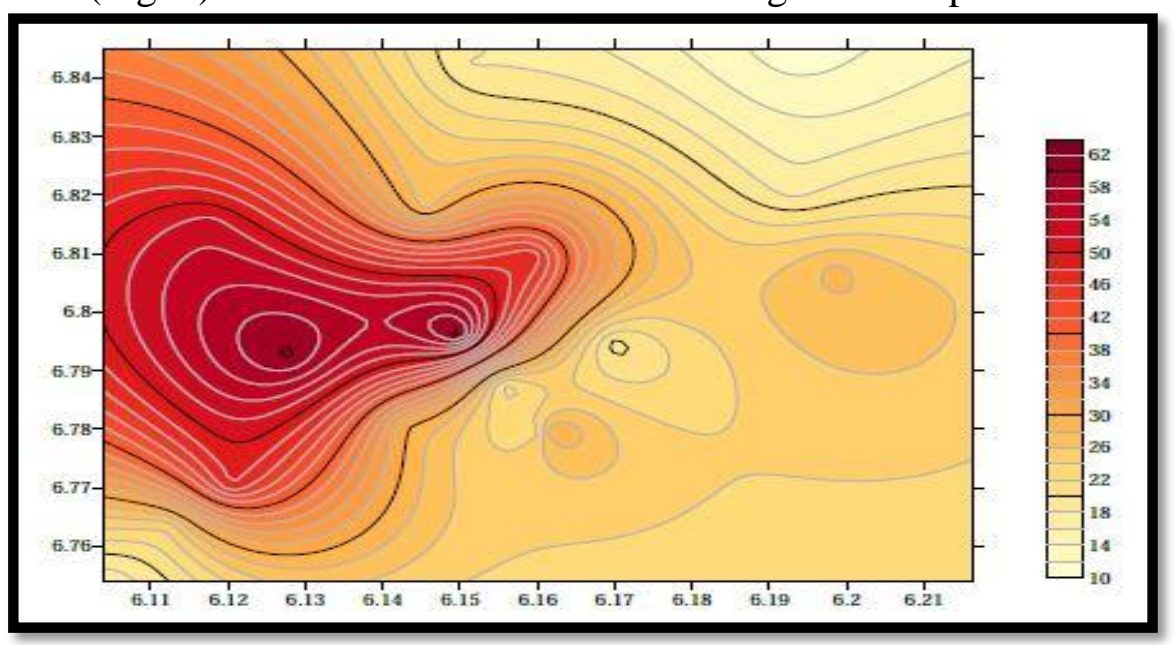

Fig. 6: Spatial Contour Map of Electrical Conductivity

Figure 7 shows the spatial contour map of Iron (Fe). Iron exceeds the permissible limit and varies from 0 to $3.769 \mathrm{ppm}$. The high concentration of Iron in the central part of the study area may be associated with the underlying geology as well as poor waste disposal and management.

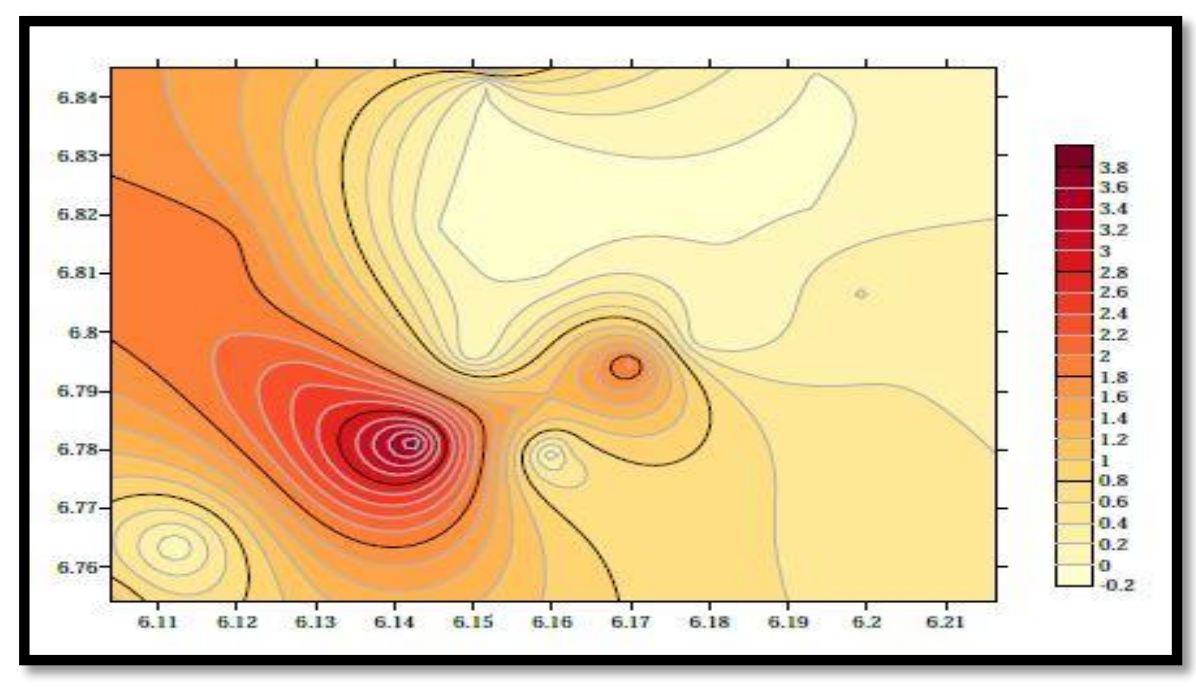

Fig. 7: Spatial Contour Map of Iron

The spatial contour map of Nickel indicates that the groundwater in the northeastern part of the study area has the highest concentration of Nickel (Fig.8). This could be as a result of agricultural activities in the area. Nickel concentration is within the permissible limit and ranges from 0 to $0.075 \mathrm{ppm}$. 


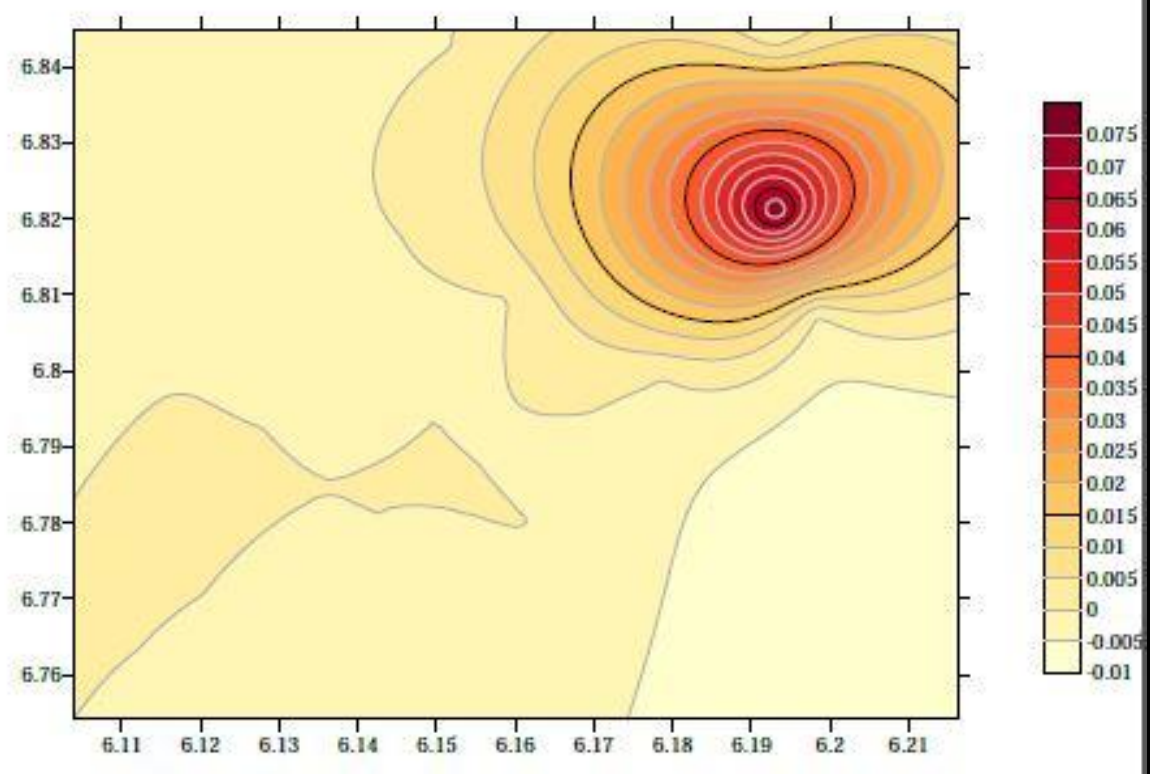

\section{Fig. 8: Spatial Contour Map of Nickel}

The $\mathrm{pH}$ value of the analyzed water samples ranges from 4.93 to 6.94 indicating water of relatively high acidity. Areas of high $\mathrm{pH}$ values in the study area are shown in Fig. 9.

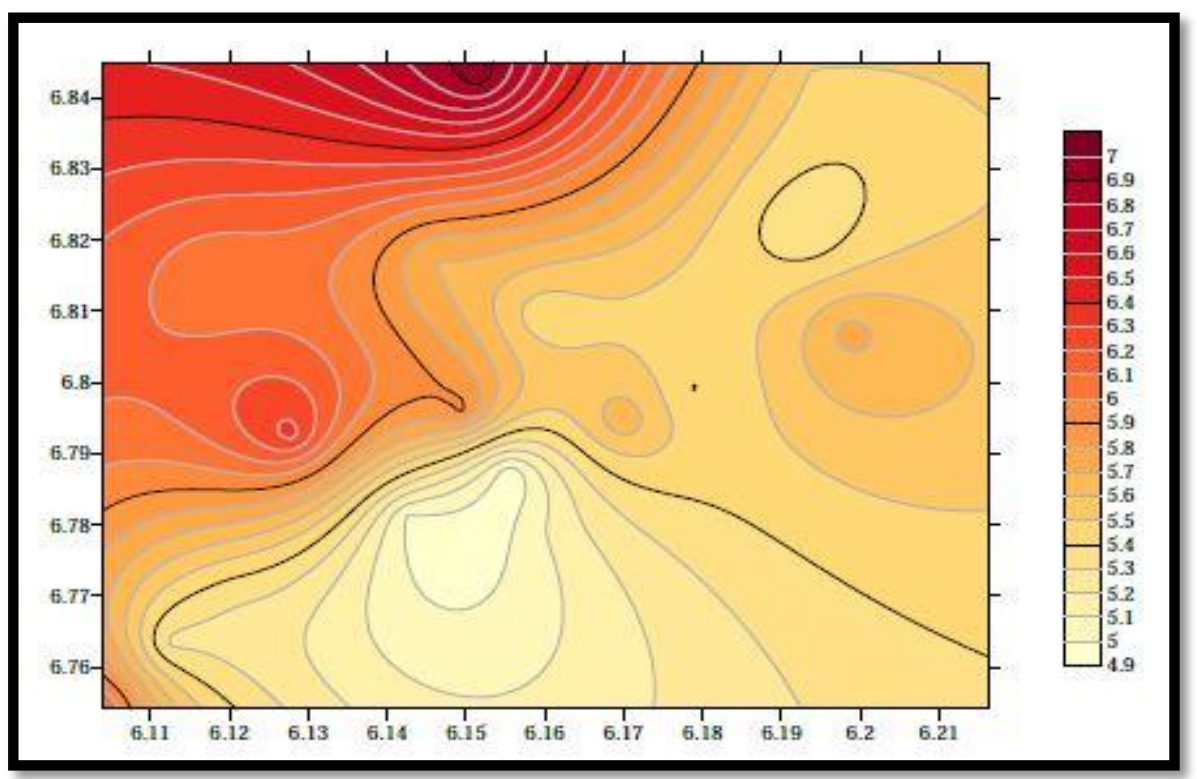

\section{Fig. 9: Spatial Contour Map of pH}

The result of the analysis recorded high Total Dissolved Solid in parts of the study area (Fig. 10). The relative high values of TDS could be attributed to the unregulated disposal of untreated wastes. 


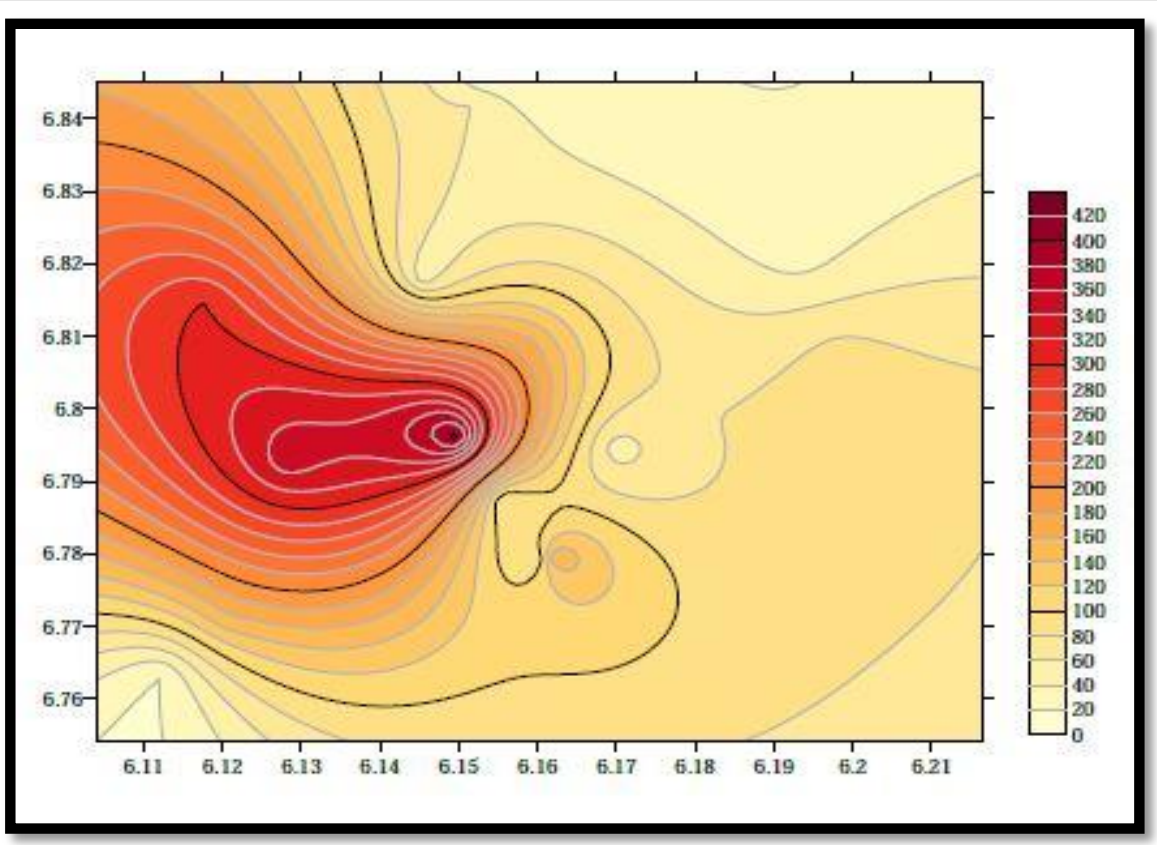

Fig. 10: Spatial Contour Map of TDS

The spatial contour map of Vanadium (Fig 11) shows that the groundwater in the southwestern part of the study area is of high concentration of Vanadium. The high agricultural activities like fishing and farming could be the reason for the high concentration of Vanadium in the area. Vanadium concentration in the groundwater samples ranges from 0 to $0.008 \mathrm{ppm}$ and this is within the permissible limit.

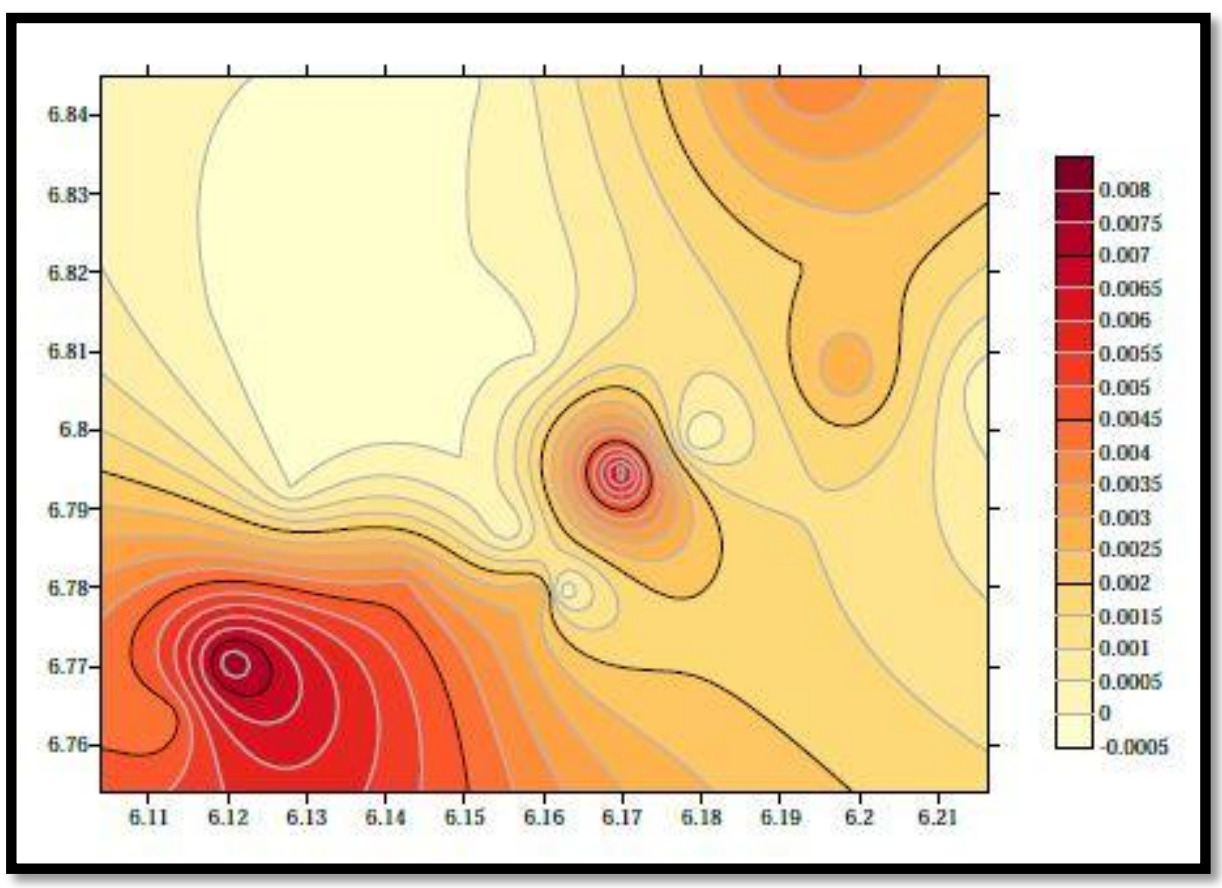

Fig. 11: Spatial Contour Map of Vanadium 
The high concentration of Zinc in the groundwater of the western part of the study (Fig. 12) could be attributed the unregulated disposal of untreated wastes because most industries within the study area dispose their wastes in the river Niger directly without treatment.

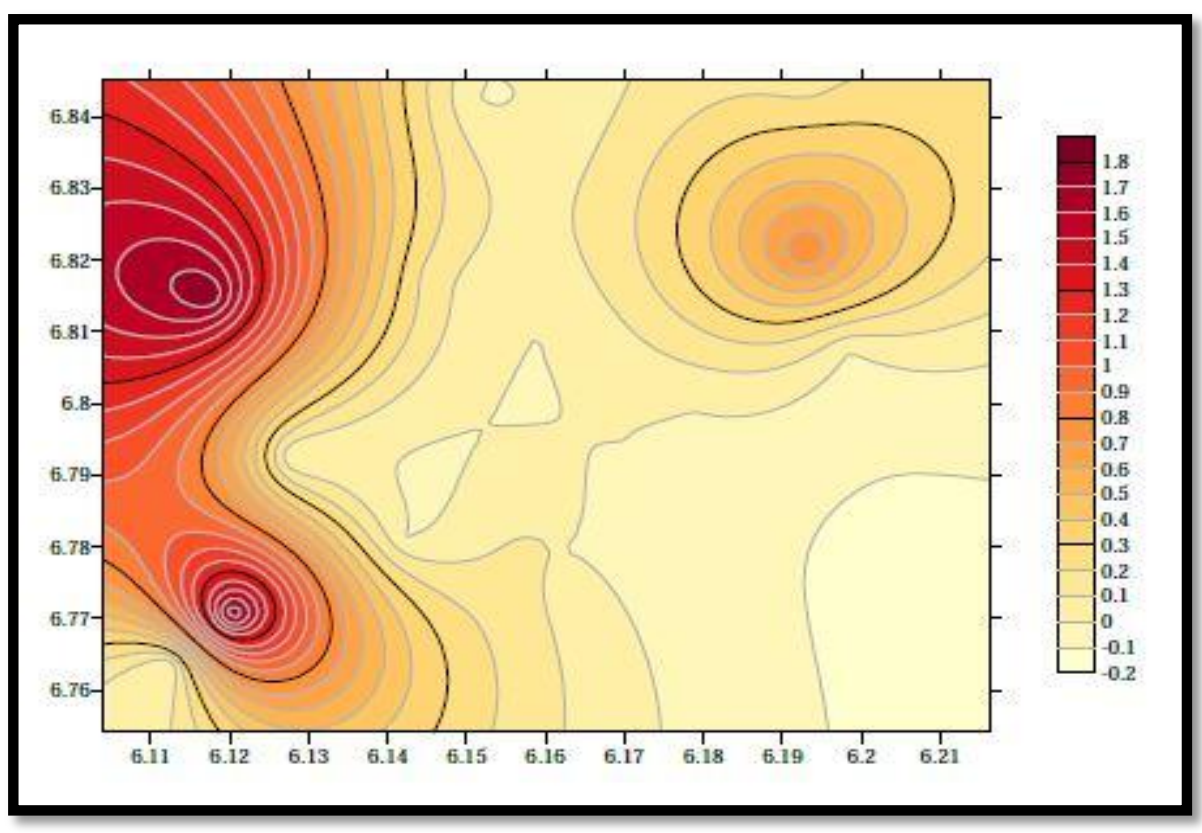

Fig. 12: Spatial Contour Map of Zinc

\section{Conclusion}

Groundwater is the only reliable water supply for drinking and irrigation purposes and it remains the largest available source of fresh water within the study Area. The activities of man have in one way or the other affected the quality of groundwater in the study area. Groundwater in the entire study area is acidic. The study revealed that Iron ( $\mathrm{Fe})$ and Cadmium (Cd) exceeded the permissible limit for NSDWQ water quality standard. The spatial contour map of the parameters analyzed in this study indicates that the eastern and central part of the study area is associated with water of poor quality when compared with the rest of the study area.

\section{Acknowledgements}

The authors are grateful to TETFUND and Nnamdi Azikiwe University for providing the fund and resources for the research.

\section{Conflict of Interest}

The authors declare that there is no conflict of interest. 


\section{REFERENCES}

American Public Health Association (APHA), American Water Works Association (AWWA) and Water Pollution Federation (WPCF) (1985).Standard Methods for the examination of Water and Waste water, 16th Edition. Washington, D. C., 1260-1268.

Egboka B.C.E and Nwankwor G.I (1985): The Hydrogeological and Geotechnical Parameters as Agents for Gully-type Erosion in the Rain-forest belts of Nigeria. Journal of African Earth sciences vol3(4); pp. 417-425.

Ezeabasili, A.C.C. and Okonkwo, A.U (2013)."Climate change impacts on the built environment in Nigeria,” African Research Review, 7(4), 288-303.

Horton RK. (1965). An index number system for rating water quality. J Water Pollut Control Adm. 37(3).

Kotadiya NG, Acharya CA, Radadia BB, Solanki HA (2013) Determination of Water Quality Index and suitability of a rural freshwater body in Ghuma village, District Ahmedabad, Gujarat. Life Sciences Leaflets 2: 68-67.

Monanu, P.C. (1975). Rainfall. In: Nigeria in maps: Eastern States, Ofomata, G.E.K. (Ed). Ethiope Publishing House, Benin City, Nigeria, Pp.25 - 26.

Nwajide, C. S., (2013). Nigeria Sedimentary Basins. pp. 321 - 332

Onwughara NI, AjiweVIE ,Nnabuenyi HO (2013). Physico-chemical studies of water from selected boreholes in Umuahia North Local Government Area, in Abia State, Nigeria. International Journal of Pure \& Applied Bioscience 1: 34-44.

Ranjana, A. (2010). Physico-Chemical Analysis of some GroundwaterSamples of Kotputli.

Sajil-Kumar P. J, Elango L, James E.J . (2013).“Assessment of hydrochemistry and groundwater quality in the coastal area of South Chennai, India."Arab J. Geo. DOI 0.1007/s12517-013-0940-3.

Uduma, A.U (2014). Physico-chemical analysis of the quality of sachet water consumed in Kano metropolis. American Journal of Environment, Energy and Power Research 2: $1-10$.

Vasanthavigar, M., Srinivasamoorthy, K., Vijayaragavan, K. (2010): Application of water quality index for groundwater quality assessment: Thirumanimuttar sub-basin, Tamil Nadu, India. Environ. Monit. Assess. Vol. 171: pp.595-609. 